\title{
HUBUNGAN KUALITAS TIDUR DENGAN KONSENTRASI BELAJAR PADA MAHASISWA KEPERAWATAN UNIVERSITAS MUHAMMADIYAH PURWOKERTO
}

\author{
Zainul Arifin ${ }^{1}$, Etlidawati ${ }^{2}$
}

${ }^{1}$ Fakultas Ilmu Kesehatan, Universitas Muhammadiyah Purwokerto, Jl. Letjen. Soepardjo Roestam Km. 7 PO. BOX 229 Purwokerto 53181

Email : arifinganteng956@gmail.com

${ }^{2}$ Fakultas Ilmu Kesehatan, Universitas Muhammadiyah Purwokerto, Jl. Letjen. Soepardjo Roestam Km. 7 PO. BOX 229 Purwokerto 53181

Email : etlidawati@yahoo.co.id

\section{Submitted : 17-04-2020, Reviewer:19-04-2020, Accepted: 19-04-2020}

\begin{abstract}
ABSTRAK
Kualitas tidur yang buruk dapat mengakibatkan penurunan konsentrasi belajar. Mahasiswa keperawatan memiliki beban akademik yang berat sehingga dapat menggangu kualitas tidur. Mengetahui hubungan kualitas tidur dengan konsentrasi belajar pada mahasiswa Keperawatan UMP. Penelitian ini menggunakan metode deskriptif kuantitatif dengan menggunakan metode cross sectional. Populasi dalam penelitian ini adalah mahasiswa Program Studi Ilmu Keperawatan semester I, III, V, \& VII yang masih aktif. Jumlah sampel 90 responden dengan menggunakan teknik proportionate stratified random sampling. Instrument ini menggunakan lembar kuesioner, dan di analisis dengan statistik uji Chi-square. Menunjukkan bahwa sebagian besar responden berumur 20 tahun sebanyak 26 (28,9\%), dan rata-rata umur responden 19,64 tahun dengan minimun 18 tahun dan maksimum 22 tahun. Secara statistik terdapat hubungan kualitas tidur dengan konsentrasi belajar dengan $p$-value $=0,000$. Adanya hubungan antara kualitas tidur dengan konsentrasi belajar pada mahasiswa Keperawatan Universitas Muhammadiyah Purwokerto.

Kata kunci: Konsentrasi Belajar, Kualitas Tidur, Mahasiswa Keperawatan.
\end{abstract}

\begin{abstract}
Poor sleep quality could result in a decreased concentration of learning. Nursing students had a heavy academic burden so that it could disrupt sleep quality. To figure out the correlation between sleep quality and learning concentration of nursing students in Universitas Muhammadiyah Purwokerto. This research used a quantitative descriptive method using the cross-sectional method. The populations in this study were the active students of the Nursing department in the semester I, III, V, and VII. The samples were 90 respondents. They were taken by using a proportionate stratified random sampling technique.Questionnaire sheets were used as the research instrument. The data then were analyzed using Chi-square test statistics. The results showed that there were 26 respondents $(28.9 \%)$ who were mostly aged 20 years. were, and the average age of respondents was 19.64 years with a minimum of 18 years and a maximum of 22 years. There was statistically a correlation between sleep quality and concentration of learning with $p$-value $=0,000$. There is a correlation between sleep quality and learning concentration of Nursing students in Universitas Muhammadiyah Purwokerto.

Keywords: Learning concentration, sleep quality, nursing students
\end{abstract}




\section{PENDAHULUAN}

Tidur merupakan kondisi dimana persepsi dan reaksi individu terhadap lingkungan mengalami penurunan (Mubarak,et all. 2015). Tidur merupakan keadaan tidak sadar dimana persepsi dan reaksi terhadap lingkungan menurun atau hilang, namun individu dapat dibangungkan kembali dengan rangsangan yang cukup (Asmadi, 2008). Kebutuhan tidur yang cukup ditentukan oleh dua faktor yaitu jam tidur (kuantitas tidur) dan kedalaman tidur (kualitas tidur). Kualitas tidur dapat 2 dinilai dari beberapa aspek seperti lamanya tidur, waktu yang diperlukan untuk dapat tertidur, frekuensi terbangun, dan beberapa aspek subjektif seperti kedalaman dan kepulasan tidur (Nilifda et all, 2016).

Kurangnya kebutuhan tidur akan berdampak pada menurunnya kemampuan untuk berkonsentrasi, membuat keputusan dan berpartisipasi dalam aktivitas seharihari. Dewasa muda yang mengalami hambatan dalam proses belajar disebabkan oleh rasa mengantuk dan lelah akibat kurang tidur, sehingga konsentrasi belajar menurun. Hal ini perlu mendapatkan perhatian yang serius karena gangguan tidur (sleep deprivation) dapat mempengaruhi proses belajar, gangguan memori dan kesehatan emosi. Konsentrasi yang baik dapat memperoleh hasil prestasi belajar yang memuaskan (Sobur, 2006).

Faktor yang menghambat dalam belajar salah satunya adalah yang berhubungan dengan jasmaniah misalnya faktor kesehatan yang sangat mempengaruhi diri anak dan prestasi belajar, sebab anak yang sakit atau lemah karena kurang tidur akan sukar belajar. Menurut hasil survei sebuah studi tidur di Inggris didapati bahwa orang yang kurang tidur cenderung 3 kali lebih besar menderita gangguan konsentrasi, 2 kali menderita kelelahan, gangguan mood, produktivitas, dan lain-lain (Marpaung, dkk, 2013).

Konsentrasi

belajar merupakan kemampuan memusatkan perhatian yang erat kaitannya dengan memori (ingatan) (Santrock, 2008). Konsentrasi memegang peranan penting bagi seorang anak untuk mengingat, merekam, melanjutkan, dan mengembangkan materi pelajaran yang diperoleh di sekolah. Kemampuan untuk mengingat, merekam, dan mengembangkan materi pelajaran yang baik memungkinkan anak memperoleh prestasi yang optimal (Hakim, 2005).

Tujuan dari penelitian ini adalah untuk mengetahui hubungan kualitas tidur dengan konsentrasi belajar pada mahasiswa Keperawatan UMP.

\section{METODE}

Penelitian ini merupakan penelitian deskriptif kuantitatif dengan menggunakan metode cross sectional. Penelitian ini hanya melakukan observasi dan pengukuran variabel pada saat tertentu saja. Pengukuran variabel tidak terbatas harus tepat pada satu waktu bersamaan, namun mempunyai makna bahwa setiap subjek hanya dikenai satu kali pengukuran, tanpa dikenai tindak 
lanjut atau pengulangan pengukuran (Saryono, 2011).

Teknik pengambilan sampel adalah probability sampling dengan menggunakan proportionate stratified random sampling. Menurut Sugiyono (2013), proportionate stratified random sampling adalah teknik yang digunakan bila populasi mempunyai anggota/unsur yang tidak homogen dan berstrata secara proporsional.

\section{Dalam}

keperawatan, kriteria sampel meliputi kriteria inklusi dan kriteria eksklusi, dimana kriteria tersebut dapat menentukan bisa atau tidaknya sampel digunakan (Hidayat 2014). Adapun kriteria sampel dalam penelitian ini adalah sebagai berikut, Kriteria inklusi antara lain : Mahasiswa yang masih aktif, Bersedia menjadi responden. Kriteria eksklusi antara lain : Mahasiswa yang tidak aktif, Mahasiswa yang sedang praktek, Mahasiswa yang sedang cuti

Jumlah sampel yang diambil dalam penelitian ini yaitu 90 mahasiswa yang memenuhi syarat penelitian. Tempat penelitian ini akan dilakukan di Fakultas Ilmu Kesehatan Universitas Muhammadiyah Purwokerto. Instumen dalam penelitian ini menggunakan kuesioner dan teknik pengumpulan data dengan cara pengisian kuesioner yang di dilakukan sendiri oleh respoden.

\section{HASIL DAN PEMBAHASAN}

\section{Karaktersitik responden}

Berdasarkan penelitian yang telah dilakukan terhadap 90 responden menunjukan sebagian besar responden berusia 20 tahun sebanyak 26 dengan persentase (28,9\%), rata-rata umur responden adalah 19,64 tahun dengan minimun 18 tahun dan maksimum 22 tahun. Sedangkan berdasarkan jenis kelamin diperoleh hasil bahwa mayoritas responden berjenis kelamin perempuan yaitu 62 orang $(68,9 \%)$ dan laki-laki sebanyak 28 orang $(31,1 \%)$ responden, seperti yang dapat dilihat di Tabel 4.1

Tabel 4.1 Karakteristik Responden Berdasarkan Umur dan Jenis kelamin

\begin{tabular}{|c|c|c|}
\hline Karalcteristilk & $F$ & $\%$ \\
\hline \multicolumn{3}{|l|}{ Umur } \\
\hline 18 tahun & 18 & 20,0 \\
\hline 19 tahun & 24 & 26,7 \\
\hline 20 tahum & 26 & 28,9 \\
\hline 21 tahun & 16 & 17,8 \\
\hline 22 tahum & 6 & 6,7 \\
\hline Rata-rata & 19,64 & \\
\hline \multicolumn{3}{|l|}{ Jenis Kelamin } \\
\hline Laki-laki & 28 & 31,1 \\
\hline Perempuan & 62 & 68,9 \\
\hline Total & 90 & 100 \\
\hline
\end{tabular}

\section{Gambaran Kualitas Tidur}

a. Kualitas Tidur Mahasiswa Tabel 4.2 Distribusi Kualitas Tidur Mahasiswa

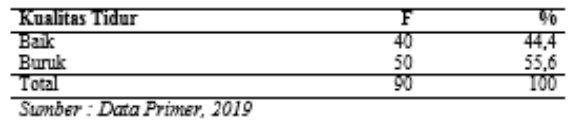

Berdasarkan tabel 4.2 menunjukan bahwa kualitas tidur yang dimiliki mahasiswa sebanyak 40 orang $(44,4 \%)$ memiliki kualitas tidur yang baik dan 50 orang $(55,6 \%)$ memiliki kualitas yang buruk.

b. Kualitas Tidur Subyektif 
Tabel $\quad 4.3 \quad$ Distribusi Kualitas Tidur Subyektif

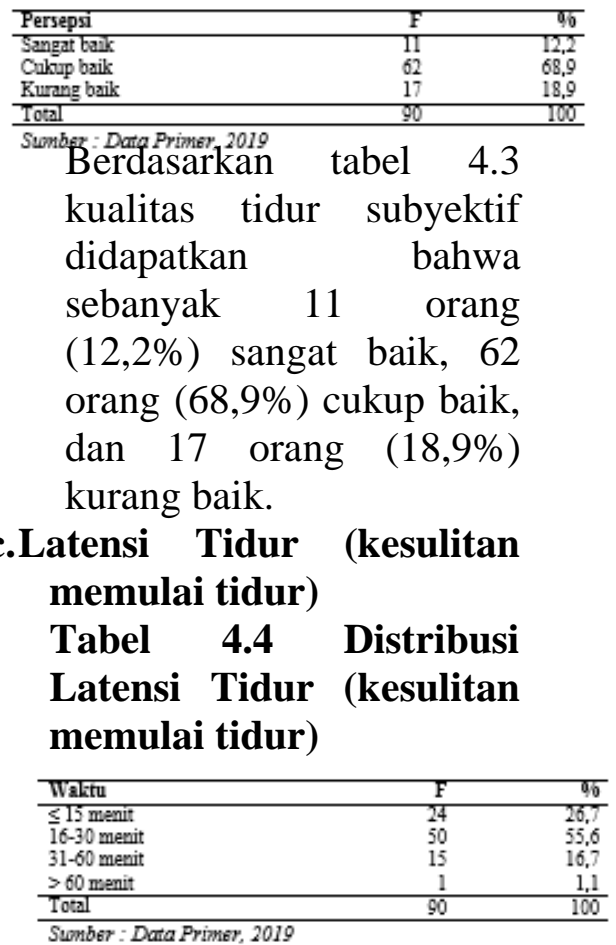

Berdasarkan tabel 4.4 latensi tidur terlihat bahwa 24 orang $(26,7 \%)$ memiliki latensi tidur yang sangat baik yaitu $\leq 15$ menit, 50 orang $(55,6 \%)$ memiliki latensi tidur 16-30 menit, 15 orang $(16,7 \%)$ memiliki latensi tidur 31-60 menit, dan 1 orang $(1,1 \%)$ memiliki latensi tidur yang buruk yaitu $>60$ menit.

d. Lama Tidur

Tabel 4.5 Distribusi Lama Tidur

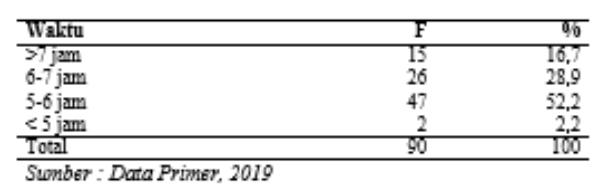

Berdasarkan tabel 4.5 lama tidur mahasiswa diperoleh hasil bahwa sebanyak 15 orang $(16,7 \%)$ yang memiliki lama tidur yaitu $>7$ jam, 26 orang $(28,9 \%)$ memiliki lama tidur 6-7 jam, 47 orang $(52,2 \%)$ memiliki lama tidur 5-6 jam dan 2 orang $(2,2 \%)$ memilki lama tidur $<5$ jam.

\section{e.Efisiensi Tidur}

Tabel 4.6 Distribusi Efisiensi Tidur

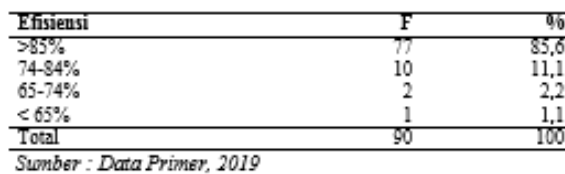

$\begin{array}{ccc}\text { Berdasarkan } & \text { tabel } \\ 4.6 & \text { efisiensi } & \text { tidur }\end{array}$ merupakan perbandingan lama tidur yang sebenernya dengan lama berada di tempat tidur. Dari hasil penelitian didapatkan bahwa 77 orang $(85,6 \%)$ memiliki efisiensi tidur yang baik yaitu >85\%, 10 orang $(11,1 \%)$ memiliki efisiensi tidur $75-84 \%, 2$ orang $(2,2 \%)$ memiliki efisiensi tidur $65-74 \%$, dan 1 orang $(1,1 \%)$ memiliki efisiensi tidur $<65 \%$.

f. Gangguan Tidur Malam Hari

Tabel $\quad 4.7 \quad$ Distribusi Gangguan Tidur Malam Hari

\begin{tabular}{lcr}
\hline Gangguan Tidur & F & $\%$ \\
\hline Tidak pernah & 7 & 7,8 \\
Sekali seminggu & 67 & 74,4 \\
2 kali geminggu & 16 & 17,8 \\
\hline Total & 90 & 100 \\
\hline Sumber : Data Primer, 2019 & &
\end{tabular}

Berdasarkan tabel 4.7 gangguan tidur malam hari, dapat dilihat bahwa 
hanya 7 orang $(7,8 \%)$ yang tidak pernah mengeluh gangguan tidur di malam hari. Sebanyak 67 orang $(74,4 \%) \quad$ mengalami gangguan tidur sekali seminggu, 16 orang $(17,8 \%) \quad$ mengalami gangguan tidur 2 kali seminggu.

g. Penggunaan Obat Tidur Tabel 4.8 Distribusi Penggunaan Obat Tidur

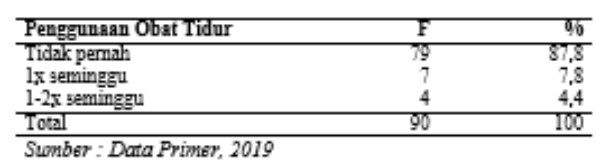

Berdasarkan tabel 4.8 penggunaan obat tidur, didapatkan hasil bahwa 79 orang $(87,8 \%)$ tidak pernah mengkonsumsi obat tidur, 7 orang $(7,8 \%)$ mengkonsumsi obat tidur 1 kali seminggu, 4 orang $(4,4 \%)$ mengkonsumsi obat tidur 1-2 kali seminggu untuk membantu tidurnya.

h. Gangguan Aktivitas di Siang Hari

Tabel 4.9 Distribusi Gangguan Aktivitas di Siang Hari

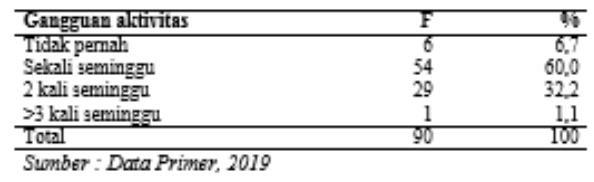

Berdasarkan tabel

4.9 gangguan aktivitas di siang hari diperoleh hasil bahwa 6 orang $(6,7 \%)$ yang tidak pernah mengeluh adanya gangguan aktivitas, 54 orang $(60,0 \%)$ mengeluh adanya gangguan aktivitas sekali seminggu, 29 orang $(32,2 \%)$ mengeluh adanya gangguan aktivitas 2 kali seminggu, 1 orang $(1,1 \%)$ mengeluh adanya gangguan aktivitas lebih dari 3 kali seminggu. Hampir semua responden mengeluh mengantuk dan lemas pada siang hari akibat kurang tidur sehingga menggangu aktivitasnya.

3.

Gambaran

\section{Konsentrasi Belajar}

a. Frekuensi Konsentrasi Belajar

Tabel 4.10 Distribusi Frekuensi Konsentrasi Belajar

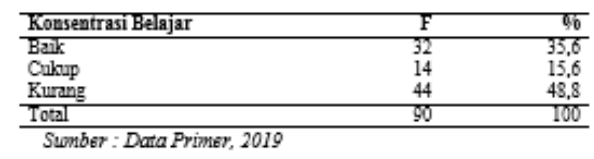

Berdasarkan tabel 4.10 menunjukkan bahwa konsentrasi belajar yang dimiliki mahasiswa sebanyak 32 orang $(35,6 \%)$ memiliki kategori baik, 14 orang $(15,6 \%)$ memiliki kategori cukup, dan 44 orang $(48,8 \%)$ memiliki kategori kurang.

4. Gambaran Hubungan Kualitas Tidur Dengan Konsentrasi Belajar Pada Mahasiswa

a. Tabel 4.11 Hubungan Kualitas Tidur Dengan Konsentrasi Belajar Pada Mahasiswa

\begin{tabular}{|c|c|c|c|c|c|c|c|c|c|}
\hline \multicolumn{10}{|c|}{ Konsentrasi Belajar } \\
\hline Kualitas & $\mathrm{Ba}$ & & & & Kur & & & & \\
\hline Tidur & $\mathrm{F}$ & 96 & $\mathrm{~F}$ & $9 \%$ & $\mathrm{~F}$ & 96 & Total & $\%$ & $P$ \\
\hline Baik & 27 & $\begin{array}{l}30,0 \\
56\end{array}$ & 5 & 5,6 & 8 & $\begin{array}{r}8,9 \\
400\end{array}$ & 40 & $\begin{array}{l}44,4 \\
55,6\end{array}$ & 0,000 \\
\hline Total & 32 & 35,6 & 14 & 156 & 44 & 48,8 & 90 & 1000 & \\
\hline
\end{tabular}


Berdasarkan data
diatas yang diperoleh
sebanyak 27 orang $(30,0 \%)$
memiliki kualitas tidur baik
disertai dengan konsentrasi
belajar yang baik, 5 orang
$(5,6 \%)$ memiliki kualitas
tidur baik disertai dengan
konsentrasi belajar cukup,
dan 8 orang (8,9\%)
memiliki kualitas tidur baik
disertai dengan konsentrasi
belajar kurang. Sebaliknya,
5 orang $(5,6 \%)$ memiliki kualitas tidur buruk disertai dengan konsentrasi belajar baik, 9 orang $(10,0 \%)$ memiliki kualitas tidur buruk disertai dengan konsentrasi belajar cukup, dan sebanyak 36 orang $(40,0 \%)$ memiliki kualitas tidur buruk disertai konsentrasi belajar kurang.

bivariat dengan

menggunakan uji Chisquare, diperoleh nilai $\mathrm{p}$ sebesar 0,000 . Seperti yang telah dijelaskan bahwa dikatakan ada hubungan jika nilai $\mathrm{p}=<0,05$ dengan tingkat kepercayaan $95 \%$ sehingga dapat disimpulkan bahwa hipotesis di terima atau ada hubungan kualitas tidur dengan konsentrasi belajar pada mahasiswa keperawatan Universitas Muhammadiyah

Purwokerto.

\section{PEMBAHASAN}

1. responden
Penelitian yang dilakukan terhadap 90 responden, didapatkan hasil bahwa responden berusia 20 tahun sebanyak 26 dengan presentase $(28,9)$, rata-rata umur responden adalah 19,64 tahun, dengan minimum 18 tahun dan maksimum 22 tahun. Lalu jenis kelamin didomisili oleh perempuan yaitu sebanyak 62 orang $(68,9 \%)$, sedangkan laki-laki sebanyak 28 orang $(31,1 \%)$. Hal ini menunjukkan bahwa minat perempuan dalam pendidikan keperawatan memang jauh lebih besar dari pada laki-laki. Profesi keperawatan yang didominasi kaum wanita disebabkan karena sikap dasar wanita yang identik sebagai sosok yang ramah, sabar, telaten, lemah lembut, berbelas kasih, dan gemar bersosialisasi. Kaum wanita dianggap memiliki naluri keibuan dan sifat caring terhadap orang lain (Gunarsa, 2008).

2.

\section{Kualitas Tidur}

Gambaran

telah dilakukan terhadap 90 responden, didapatkan hasil bahwa sebanyak 40 orang $(44,4 \%)$ memiliki kualitas tidur yang baik dan 50 orang $(55,6 \%)$ memiliki kualitas tidur yang buruk. Hal ini kemungkinan disebabkan oleh tugas-tugas kuliah yang banyak dan jadwal kuliah yang padat akan menyebabkan mahasiswa kekurangan waktu untuk tidur. Jika di hubungkan dengan teori, remaja usia 12-18 tahun memeriukan waktu tidur 8-9 jam per hari. Saat seseorang mencapai tahap dewasa, mereka cenderung memerlukan waktu tidur 7-8 jam per hari. Sedangkan lansia cenderung memerlukan waktu 6-7 jam per hari 
dengan tidur siang yang lebih sering pada siang hari. Waktu untuk tidur pada orang dewasa kebanyakan bervariasi dari tiap orang ke orang, dan umumnya berkisar antara 5-11 jam (Robotham, 2011).

Penelitian ini sejalan dengan yang dilakukan oleh Sofiyya (2015) menyebutkan bahwa remaja yang tidurnya kurang dari 78 jam dapat menyebabkan kualitas tidurnya menjadi buruk dan jika tidurnya lebih dari 7-8 jam maka kualitas tidurnya baik.

3.

Gambaran

\section{Konsentrasi Belajar}

Berdasarkan hasil penelitian didapatkan bahwa konsentrasi belajar yang dimiliki mahasiswa sebanyak 32 orang $(35,6 \%)$ memiliki kategori baik, 14 orang $(15,6 \%)$ memiliki kategori cukup, dan 44 orang $(48,8 \%)$ memiliki kategori kurang. Tingkat konsentrasi belajar mahasiswa yang mengalami kualitas tidur sebagian besar dalam kategori kurang. Gangguan konsentrasi dapat disebabkan oleh dua faktor, yaitu faktor internal dan faktor eksternal. Faktor internal merupakan faktor yang berasal dari dalam diri sendiri berupa minat belajar yang rendah atau kondisi kesehatan yang sedang buruk (Olivia, 2010).

Penelitian yang dilakukan oleh Putri (2015) di Universitas 'Aisyiyah Yogyakarta didapatkan hasil bahwa mahasiswa yang memiliki kualitas tidur buruk cenderung memiliki konsentrasi belajar kurang $(60,9 \%)$. Kurangnya waktu tidur dapat menyebabkan kualitas hidup menurun karena orang tersebut tidak memiliki cukup energi untuk melakukan aktivitas. Salah satu manfaat tidur adalah untuk mengembalikan energi agar ketika bangun di pagi hari badan terasa segar kembali, namun jika seseorang kurang tidur mereka akan sulit untuk fokus terhadap suatu hal yang dikerjakannya. Faktor eksternal merupakan faktor yang berasal dari luar individu yaitu seperti keadaan ruangan, peralatan pendukung pembelajaran, dan suasana yang kondusif (Olivia, 2010). Menurut Peterssen (2004) seseorang akan merasa lebih berkonsentrasi jika belajar dalam lingkungan yang tenang dan nyaman.

Penelitian yang dilakukan oleh Melawati (2014) menyebutkan bahwa kebisingan dapat mempengaruhi konsentrasi, hal tersebut disebabkan karena tempat yang bising akan mempengaruhi seseorang sulit berfikir sehingga konsentrasi menjadi pudar.

\section{Hubungan Kualitas Tidur Dengan Konsentrasi Belajar Pada Mahasiswa}

Berdasarkan hasil

penelitian bahwa Hubungan

Kualitas Tidur dengan

Konsentrasi Belajar Pada

Mahasiswa Keperawatan

Universitas Muhammadiyah

Purwokerto yang dimiliki mahasiswa sebanyak 27 orang $(30,0 \%)$ memiliki kualitas tidur baik disertai dengan konsentrasi belajar yang baik, 5 orang $(5,6 \%)$ memiliki kualitas tidur baik disertai dengan konsentrasi 
belajar cukup, dan 8 orang $(8,9 \%)$ memiliki kualitas tidur baik disertai denga konsentrasi belajar kurang. Sebaliknya, 5 orang $(5,6 \%)$ memiliki kualitas tidur buruk disertai dengan konsentrasi belajar baik, 9 orang $(10,0 \%)$ memiliki kualitas tidur buruk disertai dengan konsentrasi belajar cukup, dan sebanyak 36 orang $(40,0 \%)$ memiliki kualitas tidur buruk disertai konsentrasi belajar kurang. Lalu dijelaskan bahwa ada hubungan antara dua variabel jika nilai $\mathrm{p}=<0,05$. Sedangkan analisa bivariat yang telah dilakukan dengan menggunakan Uji Chi-square pada penelitian ini menunjukkan hasil analisa uji Chi Square didapatkan $\mathrm{p}$ value $=0,000(\mathrm{p}$ value $\leq 0,05$ ). Hal ini sejalan dengan penelitian dari Catur Masyeni (2010) yang memperoleh hasil terdapat hubungan antara kualitas tidur dengan konsentrasi belajar siswa dengan nilai $\mathrm{p}=0,004$.

Hal ini sejalan dengan teori yang dikemukakan oleh Ulimudiin (2011), bahwa tidur merupakan suatu proses yang sangat penting bagi manusia, karena dalam tidur terjadi proses pemulihan, proses ini bermanfaat mengembalikan kondisi seseorang pada keadaan semula, dengan begitu tubuh yang tadinya mengalami kelelahan akan menjadi segar kembali. Proses pemulihan yang terhambat dapat menyebabkan organ tubuh tidak bisa bekerja dengan maksimal, akibatnya orang yang kurang tidur akan cepat lelah dan mengalami penurunan konsentrasi.

Hal ini juga didukung oleh teori yang dikemukakan Maas (2002), bahwa proses tidur menghasilkan tenaga yang luar biasa. Tidur memulihkan, meremajakan dan memberi energi tubuh dan otak. Sepertiga hidup manusia yang seharusnya dilewati dengan tidur, berpengaruh besar terhadap dua pertiga lainnya, dalam hal kewaspadaan, suasana hati, persepsi, daya ingat, daya pikir/konsentrasi, kecekatan reaksi dan lainnya.

Penelitian ini juga didukung oleh penelitian Taiwo dan Ruth (2014) yang berjudul Sleep As A Determinant Of Academic Performance Of University Students In Ogun State, South West, Nigeria, menyatakan bahwa kualitas tidur yang buruk dapat mempengaruhi proses pembelajaran seperti terganggunya konsentrasi sesorang. Selain itu, Penelitian ini juga sejalan dengan penelitian Rika, dkk (2015), yang menyatakan bahwa ada hubungan kualitas tidur dengan kemampuan konsentrasi belajar mahasiswa program studi ilmu keperawatan universitas riau, dengan hasil analisa uji Chi Square didapatkan $p$ value $=0,002(p$ value $\leq 0,05)$.

Berdasarkan hasil penelitian, teori dan studi literature, maka peneliti berpendapat bahwa ada hubungan antara kualitas tidur dengan konsentrasi belajar, hal ini dikarenakan tidur mempengaruhi kinerja otak 
sehingga berpengaruh terhadap kondisi fisik dan psikologis seseorang. Karena seseorang yang kurang tidur akan memiliki masalah pada kecerdasan otaknya. Hal ini dikarenakan konsentrasi melemah dan membuat sistem kerja otak menjadi tumpul dan sulit untuk digunakan dalam berpikir.

Menurut Potter \&

Perry (2010), seseorang yang kurang cukup menjalani tidur jenis REM maka esok harinya akan menunjukkan kecenderungan untuk hiperaktif, kurang dapat mengendalikan diri dan emosinya, nafsu makan bertambah. Tidur NREM yang kurang cukup, akan mengakibatkan esok harinya keadaan fisik menjadi kurang gesit.

\section{KESIMPULAN}

Berdasarkan pembahasan

dalam peneltian ni, peneliti

menyimpulkan beberapa hasil

penelitian sebagai berikut :

1. Sebagian besar responden berusia 20 tahun sebanyak $28,9 \%$ ratarata umur responden 19,64 tahun. Sebagian besar responden memiliki jenis kelamin perempuan sebanyak 68,9\%.

2. Sebagian besar responden memiliki kualitas tidur buruk sebanyak 50 orang $(55,6 \%)$.

3. Berdasarkan hasil penelitian yang dilakukan untuk mengidentifikasi adanya hubungan antara kualitas tidur dengan konsentrasi belajar mahasiswa dengan menggunakan uji Chi-square, diperoleh hasil nilai ( $p$ value $=0,000)$ yang menujukkan bahwa ada hubungan antara dua variable tersebut.

\section{UCAPAN TERIMA KASIH}

Pada kesempatan ini penulis ingin menyampaikan ucapan terima kasih kepada :

1) Ns. Sri Suparti, S.Kep., M.Kep., selaku Ketua Program Studi Ilmu Keperawatan Fakultas Ilmu Kesehatan Universitas Muhammadiyah Purwokerto;

2) Ns. Etlidawati, S.Kep., M.Kep yang telah memberikan berbagai informasi dan bimbingan yang sangat bermanfaat sehingga skripsi ini dapat selesai dengan tepat waktu.

3) Ns. Dedy Purwito, S.Kep. M.Sc., Ph.D selaku Penguji 1 yang telah memberikan berbagai pertanyaan untuk menguji kelayakan sebagai sarjana Ilmu Keperawatan.

4) Ns. Deisy Sri Hardini, M.Kep., Sp. Kep.An selaku penguji 2 yang telah memberikan berbagai pertanyaan untuk menguji kelayakan sebagai sarjana Ilmu Keperawatan.

5) Kedua orang tua dan semua pihak yang telah memberikan dukungan dan do'a dalam penyusunan skripsi penelitian ini.

\section{REFERENSI}

Asmadi (2008). Teknik Prosedural Keperawatan: Konsep Dan Aplikasi Kebutuhan Dasar Klien. Jakarta: Salemba Medika.

Gunarsa, S. D. (2008). Psikologi

Keperawatan. Jakarta: Gunung

Mulia. 
Hakim, T.(2005). Belajar Secara Aktif. Jakarta: Puspa Swara.

Hidayat, A. A. 2014. Metodologi Penelitian Keperawatan dan Teknik Analisa Data. Jakarta: Salemba Medika

Nilifda H, Nadjmir, Hardisman. 2016. Hubungan kualitas tidur dengan prestasi akademik mahasiswa program studi pendidikan dokter angkatan $2010 \quad F K$ Universitas Andalas. J Kes Andalas. 5(1):243-8.

Marpaung, P,M. 2013. Gambaran Lama Tidur Terhadap Prestasi Belajar Siswa. Vol 1, No 1, hal 543-549

Maas, J.B. (2002). Power Sleep : Kiat-Kiat Sehat untuk Mencapai Kondisi dan Prestasi Puncak. Bandung : Kaifa.

Melawati, L. (2014). Pengaruh Kebisingan Lalu Lintas Terhadap Konsentrasi Belajar yang di Nilai Secara Subjektif pada Siswa Sekolah Menengah Atas di Medan Belawan. Skripsi Strata Satu, Universitas Sumatra Utara.

Mubarak, wahit Iqbal,. Et. all (2015). Buku Ajar Ilmu Keperawatan Dasar. Jakarta: $\quad$ Salemba medika.
Olivia, F. (2010). Mendampingi Anak Belajar: Bebaskan Anak Dari Stres dan Depresi Belajar. Jakarta: PT Elex Media Komputindo. Diakses pada tanggal 30 Desember 2019.

Petersen, L. (2004). Bagaimana Memotivasi Anak Belajar. Jakarta: Grasindo.

Potter dan Perry. (2010). Fundamental keperawatan buku. Edisi 7. Jakarta : Salemba Medika.

Putri, A.A. (2015). Hubungan antara Kualitas Tidur dengan Konsentrasi Belajar dan Indeks Prestasi Mahasiswa Program DIII Kebidanan STIKES 'Aisyiyah Yogyakarta. STIKES 'Aisyiyah Yogyakarta.

Rika Diah, dkk. (2015). Hubungan kualitas tidur dengan tekanan darah dan kemampuan konsentrasi belajar mahasiswa PSIK Universitas Riau. Vol. 2, No 2. Riau.

Robotham, D. , Chakkalackal, L. , Cyhlarova, E., 2011. The impact of sleep on health and wellbeing, Mental Health Foundation. (Http://www. howdicfyousleep.org Diakses pada 04 Januari 2020]

Santrock. (2008). Perkembangan Masa Hidup 
(Terjemahan Diana Angela). Jakarta: Erlangga.

Saryono. (2011). Metodologi penelitian keperawatan. Purwokerto: UPT. Percetakan dan Penerbitan Universitas Jenderal Soedirman.

Sugiyono. (2013). Metode penelitian kuantitatif, kualitatif, dan R\&D. Bandung: Alfabeta.

Sobur A. Psikologi umum. Bandung: Pustaka Setia; 2006

Sofiyya, I. (2015). Hubungan Kualitas Tidur dengan Konsentrasi Belajar pada Remaja di
Yogyakarta. Diakses

pada tanggal 21 September 2019. http://etd.repository.ugm ac.id.

Taiwo M. William. (2014). Sleep As A Determinant of Academic Performance Of University Students In Ogun State, South West, Nigeria. Vol. 10, No 13. Journal European Scientific.

Ulimudiin, B.A. (2011). Hubungan Tingkat Stress Dengan Kejadian Insomnia Pada Mahasiswa Program Studi Ilmu Keperawatan Universitas Diponegoro. Jurnal : Fakultas Kedokteran Universitas Diponegoro. 